\title{
Educomunicação e
}

mediação escolar:

um projeto

educomunicativo para a

relação Criança, Desenho

Animado e Consumo

Ana Lucia Penteado Brandão Prado

Jornalista e pós-graduada em Educomunicação: Comunicação, Mídias e Educação na Escola de Comunicações e Artes da USP.

E-mail: anabrandaoprado@gmail.com

Maria Cristina Palma Mungioli

Docente da Escola de Comunicações e Artes da Universidade de São Paulo onde atua em cursos de graduação e no Programa de Pós-Graduação em Ciências da Comunicação.

E-mail: crismungioli1@gmail.com

Resumo: O presente artigo aborda a relação entre infância e consumo a partir de seu estímulo pelas mídias contemporâneas. Partindo de uma concepção educomunicativa, defende-se que a partir da Educação para a Comunicação e da mediação escolar, o desenho animado pode ser empregado como ferramenta para educar criticamente as crianças, visando a sua formação como sujeitos ativos no processo comunicativo. Finalizamos o estudo com uma proposta de intervenção educomunicativa por meio da qual se preconiza na educação infantil a realização de atividades com desenho animado e suas personagens como meio de educar as crianças para as mídias e possíveis influências em relação ao consumo.

Palavras-chave: educomunicação; Educação para a Comunicação; infância; desenho animado; mediação.
Abstract: The paper examines the relation between childhood and consumism estimulated by contemporary midia. With a educomunicational perspective, it defends that with Education for Comunication and school mediation the animated cartoon can be used as a resource to educate children aiming their formation as active subjects in the comunicative process. We propose a educomunicational intervention with the cartoons that will help educate children to view the consumism and its propaganda with criticism.

Keywords: educomunication; Education for Comunication; childhood; cartoons; mediation. 
comunicação \& educação • Ano XXI • número 2 • jul/dez 2016

1. O estudo foi realizado pela autora Ana Lucia Penteado Brandão Prado sob orientação da Profa. Maria Cristina Palma Mungioli como trabalho de conclusão do curso Educomunicação: Comunicação, Mídias e Educação, da Universidade Estadual de São Paulo.

2. ROSENFELD, Anatol. Literatura e Personagem. In: A Personagem de Ficção. 13. ed. São Paulo: Perspectiva, 2014, pp 9-50.

3. Laboratório de Pesquisa sobre a Infância, Imaginário e Comunicações da Escola de Comunicações e Artes da USP.

4. PACHECO, Elza Dias.

O Desenho Animado na Tevê: Mitos, Símbolos e Metáforas. Relatório Final/Lapic. São Paulo: ECA-USP, 1999. Disponível em: <www. eca.usp.br/nucleos/lapic/ pesquisa/2pesquisa/2 pesquisa.html>. Acesso em: 19 maio 2015.

5. ARIÈS, Philippe. História Social da Criança e da Família. 2. ed. Rio de Janeiro: LTC, 2006.

\section{INTRODUÇÃO}

As ideias centrais deste artigo baseiam-se nos pressupostos da Educomunicação, e em suas possibilidades de subsidiar o trabalho da escola de mediação entre crianças e mídias eletrônicas. A partir desse enfoque, estudamos ${ }^{1}$ elementos da relação das crianças com personagens de desenho animado, com a finalidade de realizar um projeto de intervenção em uma escola de educação infantil.

Quando representada em uma obra de ficção, a personagem, por mais que pretenda representar a vida real, o faz de maneira mais "nítida, coerente e transparente". "Assim, o leitor contempla e ao mesmo tempo vive as possibilidades humanas que a sua vida pessoal dificilmente lhe permite viver e contemplar [...]" 2

$\mathrm{O}$ mesmo acontece em relação às personagens de desenhos animados, conforme enfatiza o relatório final do Lapic ${ }^{3}$, sobre a pesquisa O Desenho Animado na Tevê: Mitos, Símbolos e Metáforas ${ }^{4}$, quando conclui que também existe a possibilidade de o telespectador infantil viver, através das obras de ficção e seus personagens, situações que não lhes são permitidas no dia a dia.

A opção de nosso estudo justifica-se pelo entendimento de que o desenho animado é um dos produtos midiáticos de maior consumo infantil, com diversas implicações, que serão consideradas posteriormente neste artigo, no desenvolvimento intelectual e social da criança.

Nesse contexto e partindo de uma concepção educomunicativa, defendemos que com base na Educação para a Comunicação e na constituição do educador e da escola como instâncias privilegiadas de mediação, o desenho animado pode ser usado como ferramenta importante na complexa tarefa de educar criticamente as crianças em relação às mídias.

Como forma de dar vida aos achados de nossa pesquisa, propomos uma atividade de intervenção educomunicativa, que utiliza o desenho animado e suas personagens para trabalhar com alunos de 4 e 5 anos e conduzida por suas professoras. Entre os objetivos das atividades, destacam-se educar as crianças para as mídias discutindo suas possíveis influências em relação ao consumo.

\section{INFÂNCIA, MÍDIAS E CONSUMO}

O que é infância? A palavra, que deriva do latim infantia "aquele que não fala", representa na sociedade contemporânea a fase da vida que vai do nascimento até a puberdade. Apesar de hoje conhecermos o significado e a importância desse período no desenvolvimento do ser humano, sabemos que sua compreensão não se apresenta como algo constante, ao contrário, decorre de um processo histórico em permanente construção e sujeito aos tensionamentos sociais e econômicos.

Philippe Ariès ${ }^{5}$ realizou pesquisa sobre as representações das crianças em pinturas medievais. Segundo ele, naquela época, a ideia de infância não estava ligada às fases de amadurecimento humano, mas, sim, uma expressão usada para representar quem, de alguma forma, ainda era dependente do outro. 
Segundo o historiador, essa condição começou a se alterar com o que ele chamou de "surgimento da infância" marcado pela maneira como os infantes começaram a ser retratados nas obras de arte, com seus próprios passatempos e estilo de vida, a partir do início do século XVII.

David Buckingham ${ }^{6}$, pesquisador inglês que estuda a relação da infância com as mídias, cita diversos autores que enfatizam a ideia de que, se por um lado a imprensa colaborou com a configuração de infância que temos hoje, por outro, os meios de comunicação atuais - principalmente a TV - estão enterrando a infância.

O embasamento da ideia, de acordo com Buckingham, vem de Neil Postman ${ }^{7}$. Segundo ele, enquanto a imprensa era acessível apenas a quem era alfabetizado, e teoricamente apenas a adultos, a TV permite que qualquer um, letrado ou não, tenha acesso ao seu conteúdo, tornando os materiais destinados a crianças, jovens e adultos um território comum.

Ainda que a tese de Postman discuta questões importantes, como as mudanças significativas da infância contemporânea em si e de sua relação com as mídias, no seu entender os pequenos indefesos precisam ser protegidos e controlados tanto pela família, quanto pela escola, já que não são capazes de tomar decisões e serem críticos ante a sua cultura.

Decorrente da relação, está em pauta no Brasil a questão da regulamentação da publicidade infantil. No início de 2014, o Conselho Nacional dos Direitos da Criança e do Adolescente (Conanda) ${ }^{8}$, publicou no Diário Oficial da União a resolução $163 / 2014^{9}$, que considera abusivo qualquer tipo de publicidade dirigida às crianças de até 12 anos, com intenção de persuadi-las ao consumo.

O Conselho Nacional de Autorregulamentação da Publicidade (Conar) ${ }^{10}$, por duas vezes fez alterações nas normas de conduta da publicidade infantil. Em 2006, proibiu que crianças participassem da publicidade de produtos infantis e, em 2013, com proibições relativas ao marketing em programas infantis. Ainda mais radical é o Projeto de Lei n. 5.921/2001, que tramita no Congresso Nacional, propondo a extinção de qualquer tipo de publicidade dirigida a menores de 12 anos.

Do lado oposto, estão os anunciantes, publicitários e as agências de comunicação, que continuam defendendo a ideia de que a autorregulamentação, exercida pelo Conar ${ }^{11}$, ainda é o melhor caminho. O licenciamento, prática onde uma determinada marca associa-se a outra que já possua algum prestígio no mercado, para favorecer as vendas de seus produtos, é um dos pontos da discussão.

O processo que começou nos Estados Unidos, em 1903, chegou ao Brasil quase 40 anos depois, com as personagens de Walt Disney. Em 1968, Maurício de Sousa trouxe o primeiro caso de licenciamento de personagens brasileiros, com a Turma da Mônica, e desde então empresas vêm dando mais importância para o peso das personagens, principalmente quando se trata do mercado consumidor infantil.
6. BUCKINGHAM, David. Crescer na Era das Mídias: após a morte da infância. São Paulo: Loyola, 2007, pp. 43-44.

7. Postman, N. The Disappearance of Childhood, Londres: W.H.Allen, 1983, apud BUCKINGHAM, 2007 op. cit.

8. Mais informações em: $<$ www.sdh.gov.br/sobre/participacao-social/ conselho-nacional-dos-direitos-da-crianca-e-do-adolescente-conanda>. Acesso em: 20 maio 2015.

9. Resolução completa em: <www.mpba.mp.br/ atuacao/infancia/publicidadeeconsumo/conanda/ resolucao_163_conanda. pdf $>$. Acesso em: 20 maio 2015.

10. Mais informações em: <www.conar.org.br>. Acesso em: 20 maio 2015.

11. Conselho Nacional de Autorregulamentação Publicitária: Organização não governamental que visa impedir que a publicidade enganosa ou abusiva cause constrangimento ao consumidor ou a empresas. Mais informações em: <www.conar.org.br>. Acesso em: 20 maio 2015. 
12. BONFÁ, Sebastião; RABELO, Arnaldo. Licensing: Como utilizar marcas e personagens para agregar valor aos produtos. São Paulo: M.Books 2009, p. 49

13. PACHECO, Elza Dias.

O Desenho Animado na Tevê: Mitos, Símbolos e Metáforas. Relatório Final/Lapic. São Paulo: ECA-USP, 1999. Disponível em: <www. eca.usp.br/nucleos/lapic/ pesquisa/2pesquisa/2 pesquisa.html>. Acesso em: 19 maio 2015.

14. TAPSCOTT, Don. A hora da geração digital. Rio de Janeiro: Editora Agir, 2010.
Se, de acordo com Bonfá e Rabelo, a criança cria um vínculo com sua personagem favorita e, a partir dos 4 anos de idade, já é capaz de se projetar nela, humanizando-a e desejando seus atributos e características, fica claro que ao se deparar com um produto que carregue seu rosto estampado se sentirá atraída. "Pesquisas já demonstraram que produtos que utilizam um personagem, mesmo com preço $15 \%$ superior ao mesmo produto sem personagens, podem vender de $30 \%$ a $40 \%$ mais $^{12} . "$

Apesar de o desenho animado e suas personagens estimularem na criança o desejo por consumir, podem ser usados como ferramentas de mediação educomunicativa, o que poderá acarretar a utilização para a formação crítica da criança e do jovem.

[...] assim como as telenovelas, os desenhos animados também re-elaboram mitos, símbolos e metáforas que atingem a subjetividade das crianças, auxiliando-as a solucionar seus conflitos internos através de narrativas que tratam do nascimento, da vida, da morte, do herói arquetípico, da Cinderela, do príncipe encantado, do amor e outros $[\ldots]^{13}$.

Essa é a relação que pretendemos discutir, ou seja, de que maneira o produto que usa personagens licenciados para aumentar as vendas pode gerar na criança estímulo ainda maior ao consumismo. E, dentro desse quadro, como a educomunicação pode contribuir para o desenvolvimento de um consumo mais consciente, formando sujeitos ativos no processo de comunicação, capazes de entender de modo crítico a mensagem que recebem.

\section{EDUCOMUNICAÇÃO E MEDIAÇÕES}

Nem totalmente inocentes, fazendo referência a Postman e sua tese de "morte da infância", nem expert em mídias, como defende Don Tapscott, pesquisador canadense especialista em Web 2.0, que cunhou o termo Geração Internet e que afirma que estamos diante de uma geração que cresceu em meio à onda de inovações tecnológicas e por isso lida com elas com destreza ${ }^{14}$.

Pensando em um caminho intermediário, usamos um Quadro Teórico de Referência sustentado por duas vertentes. Uma delas formada pelos Estudos Culturais, cuja escolha se justifica, principalmente, pois identificamos o receptor de um processo comunicativo como um sujeito ativo.

Ao olhar para esse receptor pela primeira vez, e desconstruir a imagem trazida pelos chamados estudos frankfurtianos, que viam a cultura como um privilégio das elites, os Estudos Culturais, surgidos no final dos anos 1950 na Inglaterra, opuseram-se ao pensamento que anteriormente vislumbrava os receptores apenas como uma caixa vazia, que podia ser manipulada de todas as maneiras pelo emissor.

A outra, e que se constitui na principal vertente, é a Educomunicação, mais especificamente sua área de atuação que trata da Educação para a Comunicação 
e as possíveis mediações capazes de serem realizadas tanto pela família, quanto pela escola, na relação das crianças com os meios de comunicação.

As novas mídias descentralizaram a educação e tiraram da escola e da família o status de instância socializadora primária e detentora de todo o $\operatorname{saber}^{15}$. Não podemos afirmar que o avanço das Tecnologias da Informação e Comunicação, principalmente da internet, tornou irrestrito o acesso de todos à informação e à cultura, porém, podemos dizer que quebrou barreiras e ampliou o processo.

É nesse cenário que a Educomunicação pretende atuar. No momento em que, diante de todas as possibilidades educativas e de entretenimento que os alunos têm fora da sala de aula e que tornam a escola ainda mais desinteressante, a inserção de produtos midiáticos no ambiente escolar pode ser uma forma de estimular crianças e jovens a restabelecer o vínculo de interesse perdido com a educação formal.

Horizontalizar a educação, estabelecer o diálogo, dar voz ativa ao sujeito, esses são alguns dos pressupostos da Educomunicação para que a educação e a comunicação caminhem juntas como uma forma de emancipar o receptor. Eles se fazem presentes em nossa proposta de intervenção, pois ela pretende despertar no sujeito o interesse não só por aprender, mas também por participar do processo de aprendizagem, colaborando com a formação de um ambiente onde haja, além da troca de informações, a construção de conhecimento crítico e participativo.

Das seis possíveis áreas de intervenção da Educomunicação ${ }^{16}$, nosso foco está na denominada Educação para a Comunicação, porém a delimitação da área em questão justifica-se, pois de todas, é a que acreditamos ter os pressupostos que mais se aproximam de nossa ideia de trabalho, sem excluir as outras de serem trabalhadas concomitantemente.

Nas últimas décadas, o crescente desenvolvimento das tecnologias alteraram os processos de comunicação e a maneira com que nos relacionamos em sociedade, além da forma como buscamos ou somos alcançados pela enxurrada de informação disponível. Se hoje temos o conhecimento de uma audiência com múltiplas mediações, e que, segundo Orozco $^{17}$, transformou o receptor passivo em um sujeito ativo e criativo, capaz de ressignificar e reenviar mensagens, entendemos que foi esse o resultado das significativas mudanças que atingiram e ainda atingem nossa sociedade.

Hoje, principalmente com as redes sociais, o papel da Educação para a Comunicação, sob o olhar da Educomunicação, não é mais somente o de construir um sujeito crítico, capaz de filtrar o conteúdo divulgado por elas, mas também de formar uma audiência que consiga transformar e retransmitir a mensagem.

Se antes era fundamental formar para a recepção, agora é imprescindível formar também para a emissão e produção criativas. Isso visa tornar realidade essa cultura de participação que as redes sociais estimulam e possibilitam, mas que a maioria das audiências, pelo menos nos países ibero-americanos, ainda não assumem plenamente ${ }^{18}$.
15. MARTÍN-BARBERO, Jesús; REY, Germán. Os exercícios do ver: hegemonia audiovisual e ficção televisiva. 2. ed. São Paulo: Senac São Paulo, 2004.

16. São elas: Educação para a Comunicação; Expressão Comunicativa através das Artes; Mediação Tecnológica nos Espaços Educativos; Pedagogia da Comunicação; Gestão da Comunicação nos Espaços Educativos; Reflexão Epistemológica.

17. OROZCO, Guillermo G. Educomunicação: recepção midiática, aprendizagens e cidadania. São Paulo: Paulinas Editora, 2014.

18. CITELLI, Adilson; OROFINO, Maria Isabel. Uma apresentação entre mediações. In: OROZCO, Guillermo G. Educomunicação: recepção midiática, aprendizagens e cidadania. São Paulo: Paulinas Editora, 2014, p. 11. 
É nessa mediação que defendemos que a escola deve atuar, sem ignorar os meios de comunicação, e buscando usar sua capacidade socializadora para educar seus alunos de maneira crítica, fornecendo-lhes estímulos e estratégias para pensar os meios e a comunicação de forma ampla e consciente.

Com o passar dos anos, a televisão ganhou espaço em um lugar que antes era ocupado somente pela escola. No Brasil, de acordo com Baccega ${ }^{19}$, a questão da socialização pela TV é ainda mais forte que em outros países. Em uma sociedade pouco desenvolvida, que quase não lê jornais e que tem pouco acesso à literatura, a escola é defasada e a família se torna alvo das novas mídias. Todos esses fatores potencializam ainda mais os efeitos socializadores da TV e a influência que ela apresenta para a cultura de um povo.

Embora muitas vezes não sejam tratados claramente nas escolas, os discursos presentes nos meios de comunicação, e atualmente nas redes sociais, entram no ambiente escolar nas conversas de alunos, funcionários e professores, oferecendo-nos a justificativa para que realizemos um projeto de intervenção em educação infantil, certas da urgência que existe para que os meios de comunicação e seus produtos midiáticos "saiam da clandestinidade e passem a constituir parte dos diálogos que deveriam ocorrer em sala de aula"20.

\section{O PROJETO DE INTERVENÇÃO}

O objetivo aqui foi desenvolver com professoras de educação infantil, um projeto educomunicativo que utilize os pressupostos da Educação para a Comunicação e trabalhe com mediação entre escola e crianças, de modo que a consciência crítica comece a ser formada. Para tanto, a atividade prevê o uso em um dos momentos do trabalho de uma animação, que tem como um de seus temas principais o consumo exacerbado, que gera problemas futuros para a humanidade.

Trata-se do longa-metragem Wall-E. Lançado em junho de 2008, pelos Estúdios Disney e Pixar Animation, a animação de 97 minutos, conta a história de um robô e sua saga de recuperar a Terra, depois de as condições de vida no planeta terem sido completamente destruídas pelo lixo produzido pelos humanos.

A história começa no ano de 2.700 e mostra Wall-E (Waste Allocation Load Lifters - Earth ou Levantador de Carga para Alocação de Lixo - Classe "Terra", em português), um robô, sujo e com aparência de velho, coletando lixo, no que parece ser o planeta Terra destruído.

Como o consumo desenfreado gerou quantidades gigantescas de entulho, a vida na Terra tornou-se inviável, e como solução os humanos foram enviados

19. BACCEGA, Maria Aparecida. Televisão e escola: uma mediação possível? São Paulo: Editora Senac, 2003.

20. Idem, p. 61 temporariamente para uma base no espaço. Porém, aparentemente algo deu errado, e, em vez de voltarem no prazo estipulado, permanecem 700 anos fora do planeta.

A rotina do simpático Wall-E muda quando EVA (Extra-terrestrial Vegetation Evaluator ou Examinadora de Vegetação Alienígena, em português), uma 
robô muito mais evoluída que ele, vem cumprir uma missão sob comando dos humanos que estão na nave Axiom. Quando os robôs se encontram, Wall-E se apaixona por EVA e a trama começa.

Nosso projeto foi proposto pensando em uma escola de educação infantil, particular, de porte médio, de uma cidade do interior de São Paulo, mas tem total condição de ser replicado por qualquer outra.

A proposta de trabalho é dividida em três fases. A primeira com duração de seis semanas prevê encontros semanais. Nessa etapa, o educomunicador irá abordar com as educadoras os temas: infância, mídias e consumo. Ao longo dessas reuniões, o educomunicador irá introduzir a questão da mediação escolar na relação infância e mídias a partir dos pressupostos da educomunicação.

Frisamos aqui a importância de as atividades serem orientadas por um educomunicador, já que este saberá a maneira exata de conduzir o trabalho para que seja realizado da maneira correta e obtenha os resultados esperados.

Nessa etapa, o educomunicador e as professoras irão assistir à animação proposta e definir as atividades que serão aplicadas às crianças no segundo momento do projeto. Cabe ressaltar que como se trata de atividades que serão construídas em conjunto pelo educomunicador e pelas professoras, é possível estabelecer um eixo norteador - em nosso caso, o consumo -, porém as atividades propriamente ditas decorrerão das discussões e levarão em conta as diversas especificidades dos alunos e da própria escola.

Apenas a título de sugestão, deixamos alguns tópicos que podem ser trabalhados no projeto ou servir de base para a construção de outros, são eles: consumo e consumismo; consumo e saúde; consumo e meio ambiente; a influência da personagem licenciada no consumo.

Na segunda fase, ao longo de oito semanas e após assistirem a Wall-E com as crianças, as professoras irão trabalhar o tema dentro de atividades previamente estabelecidas na primeira etapa do trabalho de maneira educomunicativa. Essa fase será dividida em duas aulas semanais de 50 minutos cada uma e tem como objetivo, a partir do produto midiático que é o desenho animado, incentivar os alunos a pensar sobre o consumo mostrado no filme e o consumo sustentável.

A principal função das professoras no projeto é conduzir a problematização do tema, sugerindo possibilidades de ampliar a discussão, mostrando perspectivas para que os alunos possam refletir sobre ele, sempre levando em consideração e respeitando a realidade de cada um.

O educomunicador irá participar do encontro inicial com as crianças e as professoras, bem como de uma reunião entre a quarta e quinta semana de atividades, e no final.

A terceira e última fase será realizada durante a Casa Aberta, atividade que acontece anualmente na escola para a qual se construiu o projeto. No entanto, em outras escolas a atividade poderá ser realizada em evento que estejam presentes pais, professores e alunos. A organização, divulgação e realização deverão ser feitas pelas crianças com o auxílio das professoras. 
Primeiro acontece a atividade de conscientização sobre consumo sustentável, que foi previamente decidida por eles. Para encerrar, as crianças irão comandar uma Feira de Troca de Brinquedos, que também será organizada por eles, e aberta à participação de todos os alunos da escola. Constitui-se aqui o ponto essencial para a formação do aluno, pois será o momento em que se articularão os princípios educomunicativos que nortearam o trabalho e sua relação com o entorno social escolar.

Nossa proposta de intervenção justifica-se, levando-se em conta o cenário da educação brasileira hoje, no qual, muitas vezes, apesar de todo o avanço tecnológico disponível na sociedade, a escola permanece isolada. Como afirma Citelli ${ }^{21}$ : "Talvez o termo descompasso seja o mais adequado para desenhar a situação vivida pelas escolas dos ciclos fundamentais e médio diante dos meios de comunicação e das novas tecnologias".

No entanto, o fácil acesso que atualmente as crianças e os jovens vêm tendo à informação através das ferramentas midiáticas e tecnológicas desencadearam uma mudança nos moldes tradicionais da educação. Se antes o professor era quem trazia todo o conhecimento para dentro da sala de aula, hoje, com o grande desenvolvimento aos meios de comunicação de massa, essa não é mais a realidade.

\section{CONSIDERAÇÕES FINAIS}

O presente relato mostra em linhas gerais o percurso realizado para a construção de um quadro teórico e de um projeto de intervenção que permitisse avançar na discussão da relação entre infância, meios de comunicação e consumo. No entanto, é preciso mencionar como principal dificuldade a falta de abertura por parte das escolas de educação infantil para a realização do projeto.

Ainda assim, pudemos confirmar no decorrer do trabalho, que as mudanças que abarcam a sociedade contemporânea estão alterando muito mais do que a formas de comunicação. Como argumentamos, as mudanças sofridas pelo status social da infância nas últimas décadas até a quase extinção da família nuclear, ou a maneira como as crianças hoje influenciam nas compras familiares, mostram-nos um cenário de transformações complexas que envolvem entre seus atores principais a tecnologia e a comunicação.

Se o mercado utiliza as mídias tecnológicas para impor e justificar formas de consumo e, portanto, de ideologias, acreditamos que cabe à escola e ao educomunicador trabalhar de maneira coerente com os princípios da Educação para as Mídias, no sentido de proporcionar aos educandos momentos de refle-

21. CITELLI, Adilson Odair. Educação e Mudanças: novos modos de conhecer. In: CITELLI. Adilson (org). Outras linguagens na escola. São Paulo: Cortez, 2000, p. 21. xão e de tomada de posição frente ao cenário de consumo que se apresenta na atualidade. É nesse ponto que a Educomunicação torna-se fundamental, estabelecendo relações horizontais, a fim de promover o diálogo e dar ao sujeito a capacidade de liberdade, a ponto de alterar a realidade que o cerca, ela é, 
entre outras propostas, fundamental na mediação escolar na relação infância e mídias.

Enfatizamos ainda que o desenho animado e suas personagens, usadas neste trabalho como objeto principal para o estudo da mediação educomunicativa, são produtos midiáticos de extrema importância no desenvolvimento infantil. Entre outras características, o desenho animado possibilita que o imaginário infantil viva experiências que não poderiam ser vivenciadas no seu dia a dia real, estimulando sua capacidade imaginativa e de autoconhecimento.

Cabe destacar que o que se espera de um educomunicador não é simplesmente que ele seja capaz de dominar os avanços tecnológicos para inseri-los nos ambientes educativos. Muito mais do que isso, é necessário que ele realmente possa mediar o contato das crianças com essas mídias e, principalmente, com o conteúdo de seus produtos.

Tal mediação, além de colaborar com o entendimento do tema por parte das crianças, tem a função de, desde a infância, formar sujeitos críticos e ativos, capazes de crescer e desenvolver cada vez mais a capacidade de atuar como cidadãos transformadores da sociedade na qual estão inseridos.

\section{REFERÊNCIAS BIBLIOGRÁFICAS}

ARIÈS, Philippe. História Social da Criança e da Família. 2. ed. Rio de Janeiro: LTC, 2006.

BACCEGA, Maria Aparecida. Televisão e escola: uma mediação possível? São Paulo: Editora Senac, 2003.

BONFÁ, Sebastião; Rabelo, Arnaldo. Licensing: Como utilizar marcas e personagens para agregar valor aos produtos. São Paulo: M.Books, 2009.

BUCKINGHAM, David. Crescer na Era das Mídias: após a morte da infância. São Paulo: Loyola, 2007.

CITELLI, Adilson Odair. Educação e Mudanças: novos modos de conhecer. In: CITELLI. Adilson (org). Outras linguagens na escola. São Paulo: Cortez, 2000.

OROFINO, Maria Isabel. Uma apresentação entre mediações. In: OROZCO, Guillermo G. Educomunicação: recepção midiática, aprendizagens e cidadania. São Paulo: Paulinas Editora, 2014.

MARTÍN-BARBERO, Jesús; REY, Germán. Os exercícios do ver: hegemonia audiovisual e ficção televisiva. 2. ed. São Paulo: Senac São Paulo, 2004.

OROZCO, Guillermo G. Educomunicação: recepção midiática, aprendizagens e cidadania. São Paulo: Paulinas Editora, 2014.

PACHECO, Elza Dias. Considerações finais do relatório final/Lapic. In: O Desenho Animado na Tevê: Mitos, Símbolos e Metáforas. São Paulo: ECA-USP, 
1999. Disponível em:<www.eca.usp.br/nucleos/lapic/pesquisa/2pesquisa/2_ pesquisa.html>. Acesso em: 19 maio 2015.

POSTMAN, N. The disappearance of childhood, London, W.H.Allen, 1983.

ROSENFELD, Anatol. Literatura e Personagem. In: A Personagem de Ficção. 13. ed. São Paulo: Perspectiva, 2014, pp. 9-50.

TAPSCOTT, Don. A hora da geração digital. Rio de Janeiro: Editora Agir, 2010. 